
[THIS PENULTIMATE VERSION MAY DIFFER SLIGHTLY FROM THE PUBLISHED VERSION.
PLEASE DO NOT QUOTE WITHOUT MY PERMISSION]

\author{
Nietzsche's Metaphysics in the Birth of Tragedy.
}

It is often assumed that the main assertions of the Birth of Tragedyabout the Apollonian, the Dionysian, and more generally the function of art, rest on an implicit core of Schopenhauerian metaphysics, which Nietzsche would later have criticised and rejected ${ }^{1}$. As stated by J. Young, there is "fairly wide agreement that the Birth incorporates without modification Schopenhauer's metaphysics" 2 (Young 2001: 26); according to him, the real core of dispute among commentators is whether Nietzsche adopts Schopenhauer's pessimistic conclusions about the value of life, Young's own controversial stance on this being that "on the crucial question of pessimism, the Schopenhauerian assessment of the worth of human existence is (...) endorsed" 3 . In this paper, I shall argue that this conclusion, based on the assumption that the Birth's metaphysics is thoroughly Schopenhauerian, must be rejected because the premise itself is unwarranted. I am aware that this is a paradoxical claim: there are many Schopenhauerian elements in the Birth, in particular the idea that the Grundstimmung of the will is pain, or that individuation is illusory ${ }^{4}$. However, if one tries to read them as supporting Nietzsche's claims about art and its redemptive power, then many difficulties and even contradictions appear. For example, if the primal affect of the world is purely pain, as in the World as Will and Representation, how can the Dionysian, which mimics it, be both painful and pleasurable? If individuation is, as in Schopenhauer's thought, an illusion due to the principle of sufficient reason, how can the Dionysian, which lifts this illusion and reunites us with the will, be also defined as "an illusion spread over things" (BT: 109)? Along the same lines, if individuation is, again in Schopenhauerian fashion, the "primary cause of evil" (BT: 74), or a "curse" (BT: 71), how can the Apollonian, which glorifies it, be a desirable illusion? And if human existence is absurd suffering, how can art, which tells us, both in its Apollonian and Dionysian forms, that life is worth living "eternally", be truthful, as Nietzsche claims?

I shall argue that the main reason for these difficulties is not really that Nietzsche's allegedly Schopenhauerian assumptions do not support his own conclusions about art: it is that his metaphysical assumptions are extremely complex and, in fact, often of a very unschopenhauerian nature. Indeed, if we focus on the metaphysical core of the Birth, leaving temporarily aside the question of the Apollonian and the Dionysian, more tensions and contradictions appear. These are centred mostly around three issues: the nature of the will (one or divided), the status of individuation (illusory or real) and the possibility of artistic redemption, both for the will and for us. In the first part of this paper, I shall identify both the Birth's Schopenhauerian elements and the reasons why early Nietzsche's metaphysics should, overall, be construed as non-Schopenhauerian. I shall then show that once teased out, this "artist's metaphysics" provides a much better ground to understand the Apollonian and the Dionysian and the redemptive function of art. Finally, I shall question the status of this metaphysics in Nietzsche's thought, with a view to establishing a) whether Nietzsche attributed any truth value to it (and in which sense) and b) the role it plays in his early work. Many commentators (in particular De Man: 1979, Poellner: 1998, Porter: 2000) have argued that Nietzsche cannot have been serious about the Birth's metaphysics and that consequently it must be seen as a myth and ultimately discarded (although the proposed interpretations of the nature and function of myth differ quite widely). In response to these claims, I shall suggest that Nietzsche was serious about this metaphysics precisely insofar as he saw and offered it as a myth, a somewhat paradoxical 
statement which, in order to be backed up, will need a re-examination of early Nietzsche's understanding of the relation between knowledge, myth and metaphysical truth.

At first sight, the Birth's metaphysics does seem rather Schopenhauerian. Nietzsche describes the will as the "Ur-Eine", the "mysterious primordial unity" (BT: 37). In accordance with Schopenhauer's teaching, it is "indivisible", the "nucleus of nature, the true being, (...) the sphere of eternal being, the inaccessible One and Eternal" 5 (KSA I: 7 [167]). The will is the metaphysical essence of the physical world, and its fundamental affect is pain: thus, the Birth evokes "suffering, primal and eternal, the sole ground of the world" (BT: 45, my italics), or the "inchoate, intangible reflection of the primordial pain in music" (BT 49: my italics). As in chapter 28 of the World as Will and Representation, the cause of this pain is attributed to the will's ever wanting nature, which makes fulfilment and thus happiness impossible: "suffering, nostalgia, lack as originary sources of things. Can true being avoid suffering? Pain is being in itself" (KSA I 7 [165]) ${ }^{6}$. This fundamental pain is aggravated by the phenomenal divisions born from the use of the principle of individuation, which is thus seen by Nietzsche too as "the origin and the primal cause of all suffering" (BT: 72), and "something objectionable in itself" (BT: 73). The reason for this is, again, Schopenhauerian: book IV of WWR shows us that the will's suffering is deepened by the fact that although it is one in essence, it is torn apart by the constant wars that its objectifications (i.e. empirical entities) wage against each other. Therefore the will, although noumenally united, is phenomenally divided, or, in Nietzsche's words, "torn asunder and shattered into individuals" (BT: 73) which permanently enter into conflict. Conversely, although the sufferings caused by individuation are real, for both authors there is the (desirable) possibility that if we manage to shift from our perspective to that of the will, the "veil of Maya (Schopenhauer's other name for the principle of individuation) will be, again in Nietzsche's words, "torn aside and now fluttering in tatters before the mysterious primordial unity" (BT: 37), and the will shall be reunited with itself (Nietzsche's "gospel of universal harmony", ibidem).

However, this Schopenhauerian reading makes the Birth's account of both the Apollonian and the Dionysian very problematic. The first is defined as a "blessed continuance in will-less contemplation" (BT: 131). The notion of a "will-less contemplation" of the beautiful images of the Apollonian dream world comes directly from Schopenhauer, who defined artistic contemplation as the result of the genius' native ability to shift from the empirical perspective, from which phenomenal struggles are real, to the transcendental standpoint, from which phenomenal individuation and its woes vanish. In book III of WWR, this shift is symbolised by the transition from the empirical individual, caught in the network of his everyday interests, to the "pure subject of knowledge" whose disinterestedness allows him to become the "clear mirror of the world" (WWR II: 380). Nietzsche explicitly takes up this idea in the following passage: "[the self of the artist] is not the same as that of the walking, empirically real man, but the only truly existent and eternal self resting at the basis of things, through whose images the lyric genius sees this very basis" (BT: 51). Both for Schopenhauer and for Nietzsche, the main effect of this detached, visionary ability (and the reason why it is valuable) is a stilling of the will, which, lulled by the beauty of the ideas, temporarily stops its endless striving and is thus freed from the evils of phenomenal individuation. However, the logical precondition for the required shift from the empirical to the transcendental perspective is the possibility for the genius to bypass the use of the principle of sufficient reason - otherwise the empirical standpoint would be maintained and no identification with the will would be possible. This is why in WWR, artistic contemplation has its specific objects, the ideas. As "permanent, unchangeable forms" (WWR II: 364), the perception of which is usually obscured by the phenomenal world $^{7}$, these ideas are transcendentally individuated, in a way which remains mysterious as it is meant to be independent from time, space and causality, which form the conditions for empirical individuation. The existence of such objects is crucial because it grounds the artist's claim to beauty 
and to a higher truth than empirical forms of knowledge, which only focus on changeable phenomena; it is also what makes Schopenhauer's views on artistic contemplation consistent.

As we have just seen, for Nietzsche too the Apollonian artist is supposed to perform the shift from the empirical standpoint to its transcendental counterpart, and to adopt a universal perspective from which phenomenal distinctions appear dreamlike and induce a state of fascinated repose. Thus, the Apollonian is a "dream reality" (BT: 34), a "continuously manifested representation of the primal unity" (BT: 45). However, nowhere in the Birth does Nietzsche take up Schopenhauer's notion of "grades of beings" (WWR II: chapt. 23), nor of the ideas as a higher and truer degree of objectification of the will (WWRII: chapt. 29) ${ }^{8}$. More generally, there is no indication that he wants to take up Schopenhauer's revival of Platonism. Consequently, the only objects left for Apollonian contemplation are empirical appearances, while the difference between Apollonian "will-less contemplation" and the everyday use of the principle of sufficient reason becomes the fact that in artistic contemplation, these appearances are glorified. Thus the Apollonian is also called by the Birth the "sublime expression" of the "unshaken faith in the principium [individuationis] and the calm repose in it" (BT: 36). The clearest example of this glorification of phenomenal appearances is the Greek projection of the Olympian world, in which the Gods are the magnified images of human individuals. Thus, "in order to glorify themselves, [the will's] creatures had to (...) behold themselves again in a higher sphere (...). This is the sphere of beauty, in which they saw their mirror images, the Olympians" (BT: 44, my italics). However, the idea that the proper objects of Apollonian contemplation are glorified phenomenal appearances is incompatible with the other requirement examined above, i.e. the necessity for the artist of a shift to the transcendental standpoint. As we have seen, such a shift must by definition cause the genius to turn away from all empirical appearances (hence Schopenhauer's fundamental claim that artistic contemplation is "beyond the use

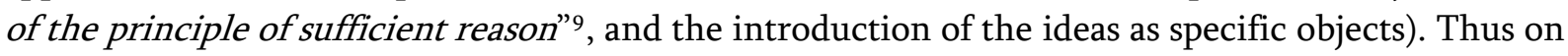
the metaphysical premises examined so far, one has to conclude that the Birth exhibits a contradiction between the method whereby the Apollonian state can be achieved (the shift to the transcendental standpoint) and its objects (glorified phenomena, which from that standpoint should vanish as transcendentally ideal).

This metaphysical difficulty is compounded in the Birth by a moral one, which was absent from Schopenhauer's account of art. The problem is that since phenomenal individuation has been identified as "the primary evil", it makes little sense to think that the will could truly find salvation in its magnification. This is why in WWR the artist must turn away from all forms of empirical individuation, towards the ideas - the highest form of art being the one that doesn't even need the mediation of the ideas, i.e. music. On this Schopenhauerian logic, the Apollonian glorification of individuation suggested by the Birth is actually dangerous, because hides the real nature of the empirical world and seduces the will into wanting the very thing that worsens its suffering - a world of individuated phenomena.

In a similar way, the Schopenhauerian premises examined so far, while illuminating some aspects of the Dionysian, also make its definition fairly inconsistent. Again, the difficulties are of a moral and metaphysical nature. From a moral perspective, the notion of a primordial noumenal suffering grounds the Nietzschean idea that human existence, as its phenomenal objectification, is essentially doomed to the "horrors" so intensely felt by the archaic Greeks (BT: 42), which in turn justifies the darker sides of the Dionysian: the wisdom of Silenus ("what is best is utterly beyond your reach: not to be born, not to be, to be nothing. But second best for you is - to die soon!" (BT: 42)), or the nausea that strikes the Dionysian man once he has acquired an "insight into the horrible truth" and "now sees everywhere only the horror or the absurdity of existence"10 (BT: 61). However, on these Schopenhauerian premises it is difficult to see why the Dionysian should be a joyful principle, let alone as a redemptive one. Nietzsche speaks of the "joyous hope that the spell of individuation 
may be broken in augury of a restored oneness" (BT: 74): That there should be hope in the shattering of individuation is consistent with his Schopenhauerian premises - book IV of WWR is devoted to the analysis of the various ways ${ }^{11}$ in which the will can become aware of itself, and thus avoid tearing at itself through its objectifications. However, "restoring oneness" would hardly be sufficient to guarantee joy, since the will is doomed by its ever wanting nature to eternal suffering. This is why in Schopenhauer's thought the only reasonable course of action for the ascetic or the burned out individual is self extinction - not suicide, which would be the paradoxical assertion of a failed aspiration to live, but a passive relinquishing of the desire to exist, such as death by starvation.

From a metaphysical point of view, the problem is that the Birth's alleged Schopenhauerian metaphysics makes it very hard to understand how the Dionysian could be seen as an illusion. Most commentators read the opposition between the Apollonian and the Dionysian as one between illusion and truth ${ }^{12}$, and indeed there are quotes which suggest that such is the case. On this reading, whereas the Apollonian covers over the dark nature of existence by generating beautiful images, the Dionysian removes the mirages of Maya and thus reveals the true nature of the will. However, the Dionysian too is defined by Nietzsche as an illusion. This is suggested by his recurrent insistence on intoxication: the Birth mentions that under the "charm of the Dionysian", man's "very gestures express enchantment" (BT: 37), and defines the Dionysian as an "intoxicated reality" which tries to redeem the individual "by a mystic feeling of oneness" (BT: 38) ${ }^{13}$. But the most explicit passage is in Section 18, which sees it as "an illusion spread over things", more precisely as one of the "three stages of illusion designed (...) for the more nobly formed natures" (BT: 110). The other two illusions are the "Socratic love of knowledge" and "art's seductive veil of beauty". The first is illusory because theoretical optimism thinks that existence is intelligible for human beings, and that it can even be corrected, i.e. made entirely happy, and the second, because it hides the necessity of human suffering by means of its beautiful Apollonian images. However, from a Schopenhauerian perspective the Dionysian lifting of the veil of Maya makes no sense as an illusion: the breaking down of the principle of individuation is seen by Schopenhauer not only as desirable, but also as truthful, in the adequationist sense that it gives human knowledge a content which reflects the real nature of the world: it shows the noumenal unity of the will behind its empirical multiplicity. This is why WWR deems the knowledge of both the artist and the ascetic superior to that of the historian or the scientist, who focus on the world of individuation and only acquire an understanding of phenomena. Consequently, if the Birth's perspective was fully Schopenhauerian, it would make no sense for Nietzsche to state that the Dionysian is an illusion, an idea which, I shall argue, can only be explained from the perspective of his own metaphysics.

So while grounding some of the aspects of the Dionysian, Nietzsche's Schopenhauerian assumptions fail to explain it should be seen as an illusion, let alone a joyful one. As we have seen above, they also make his account of the Apollonian inconsistent. More generally, they fail to account for the redemptive nature of art. Indeed, if the Dionysian lifting of the Apollonian illusions shows us nothing but the horrors of existence, how (and why) could art act as a "saving sorceress, expert at healing" (BT: 60) and persuade us that life is desirable? To use a Schopenhauerian metaphor, this would be like giving a famished mendicant the alms that will allow him to beg anon the next day. There thus seems to be a blatant contradiction between the terrible content of the Dionysian vision and the optimistic meaning attributed to it by the Birth. In his very interesting interpretation of Nietzsche's views on art, Julian Young partially solves this problem by explaining that artistic redemption should be seen as pertaining exclusively to the will. The main supporting quote for his interpretation is the following: "we may assume that we are merely images and artistic projections for the true author, and that we have our highest dignity in our significance as works of art - for it only as an aesthetic phenomenon that existence and the world are eternally justified - while of course our consciousness of our own significance hardly differs from that which the soldiers painted on 
canvas have of the battle represented on it" (BT: 53). So whereas the human actors keep on waging their endless and painful wars, the will absorbs itself in the play and forgets about its own suffering (to say that it enjoys the drama would be too much, since on this Schopenhauerian picture, happiness is just the cessation of pain). Existence is justified as an aesthetic phenomenon from a noumenal point of view, because it provides the will (not us) with a way to escape from the pain intrinsic to life ${ }^{14}$. Young's criticism of this thesis is that although it explains why art is redemptive for the will, the vision of redemption provided is very unhelpful for human beings. The evils of the world are justified for the $U r$-Eine, not for us. The closest we can come to partaking in salvation is by shedding our individuality and our human perspective in order to embrace the standpoint of the will, a feat which is only possible for the very few geniuses that history has known. For ordinary people, there is no hope that their suffering will ever be alleviated. To say that "we have our highest dignity and significance as works of art" (BT: 52) hardly provides us with any motivation to go on living: In Young's words, "to suggest otherwise would be to suggest that because a concentration camp "justifies" itself to its sadistic (...) commandant as a pleasurable "entertainment", so too must the inmates find it justified" (Young, 2001: 52). On this view, the "metaphysical comfort" (BT: 104) of tragedy is a lie ${ }^{15}$.

However, this negative assessment is dependent on the premise (adopted by Young) that Nietzsche's metaphysics is thoroughly Schopenhauerian. I would now like to suggest a different account of the Birth's metaphysics, and show that it provides a better grounding for the Apollonian, the Dionysian, and the redemptive function of art.

The first modification brought by this second reading is the claim that contradiction is a noumenal feature of the will, not the result of individuation. Thus, a fragment indicates that "individuation is a result, not the cause of suffering" (KSA I: 7 [117], a point to which I'll get back soon. The Birth mentions the "eternal contradiction, father of things" (BT: 45), the "primordial pain and contradiction at the heart of the Ur-Eine" (BT: 55), or again "the primal unity, its pain and its contradiction" (BT: 49). The reason why the will is now seen as contradictory is that it is torn between two opposite affects, pain and pleasure. Thus "the belonging together of pain and pleasure in the essence of the world is what we live from" (KSA I: 7 [196]). A passage of the Birth describes this noumenal co-belonging in more metaphoric terms: "suppose a human being has thus put his ear, as it were, to the heart chamber of the world will and felt the roaring desire for existence pouring from there into all the veins of the world (...), how could he (...) endure to perceive the echo of innumerable shouts of pleasure and woe in the "wide space of the world night", enclosed in the wretched glass capsule of the human individual, without inexorably fleeing toward his primordial home?" (BT: 130). How do the "shouts of pleasure and woe" relate to each other? The Nachlass suggests that pleasure is constantly generated by the will in an effort to counterbalance its suffering: "present life as an incredible suffering which produces endlessly, at each moment, a strong feeling of pleasure through which, insofar as we feel, we reach a certain balance and even quite often an excess of pleasure" (KSA I: 7 [202]). Although the will's suffering remains primary in that it is the motivating drive for the production of pleasure, Nietzsche departs doubly from the Schopenhauerian model: firstly, he sees pleasure as a positive force, not only the cessation of pain; secondly, he also asserts the possibility of pleasure overcoming pain ("an excess of pleasure"). This overcoming is not dialectical in the sense that the contradiction cannot be aufgehoben by means of a third term: "insofar as contradiction is the essence of the Originary One, the latter can be at the same time supreme pain and supreme pleasure" (KSA I; 7 [157]). Nor is the production of pleasure a cumulative process which would allow for a final reckoning, an Erinnerung which would reveal that the final sum of pleasures weighs more than that of pain. The overcoming of pain by pleasure is an instantaneous process compared by Nietzsche to a "continual spasm"16. 
The idea that the primordial affects of the will are contradictory, and that pleasure might, at each moment, exceed pain is enough in itself to open up a possibility which was closed on the Schopenhauerian picture, i.e. the notion that existence might be, after all, pleasurable and thus worthwhile, at least for the will. It also offers a much more promising ground to understand the redemptive function of art for human beings, a point to which I'll come back later. What we now have to understand, however, is how pleasure is produced out of suffering (the Schopenhauerian view would rather be that pain just begets more pain), and why it can even exceed pain. Nietzsche's vision of this process becomes radically un-schopenhauerian. The will, far from being "the inaesthetic in itself" (BT: 55), a blind noumenal principle endlessly striving for more (and constantly thwarted because of the infinite nature of this striving), becomes a "Dionysian world artist" who exults in creating and destroying worlds in order to alleviate its pain, in an endlessly repeated cycle. Its main characteristic is now its "prodigious artistic capacity" (KSA I: 7 [169]). Thus, "the artistic power of all nature reveals itself to the highest gratification of the primordial unity. The noblest clay, the most costly marble, man, is here kneaded and cut, and to the sound of the chisel strokes of the Dionysian world artist rings out the cry of the Eleusinian mysteries: "do you prostrate yourselves, millions? Do you sense your Maker, world?" (BT: 37-8) ${ }^{17}$ The activity of the will is now seen as an ontological form of poiesis whereby worlds are endlessly generated and destroyed. The will is the "eternally creative primordial mother, eternally impelling to existence, eternally finding satisfaction in this change of phenomena" (BT 104). Correlatively, individuation, far from being the result of our use of the principle of sufficient reason, now becomes transcendentally real (phenomena are "impelled to existence" in the sense of being produced by the will as its "creatures" (BT: 44)). The world and its entities are created, not constituted - thus, the tragic artist" "creates his figures like a fecund divinity of individuation" (BT: 132), while another passage mentions the "eternal and original artistic power that first calls the whole world of phenomena into existence" (BT: 143).

In this second metaphysics, the distinction between the phenomenal world and noumenal reality undergoes a deep transformation: the world is now seen as an artistic creation by the will, not as the subjective transposition of an unknowable in itself by means of the principle of sufficient reason. The new ontological model is in part provided by the Pre-Socratics: "thus the dark Heraclitus compares the world-building force to a playing child that places stones here and there and builds sand hills only to overthrow them again" (BT 142) ${ }^{18}$. In Fragment 30, Heraclitus identified the fundamental power of $P y r$, fire, as that of poiesis, i.e. a creative power (as opposed to praxis as the dimension of action, not production). This power must be distinguished from the human forms of poiesis in the sense that it does not obey the mundane logic of production: it does not aim at making useful or valuable objects, and more importantly, it is both creative and destructive. The most original form of poiesis, therefore, takes the form of a cosmic game whereby the will randomly creates and destroys human individuals in order to alleviate its pain. - Nietzsche evokes the "playful construction and destruction of the individual world as the overflow of primordial delight" (BT: 142). This model is expanded upon by Eugen Fink in Spiel als Weltsymbol, for whom play becomes a "cosmic metaphor for the apparition and the disappearance of things, beings, in the time and space of the world" ${ }^{19}$. In his interpretation of Heraclitus, Fink too insists on the duality of the cosmic fire, which both begets individuals and kills them: "the drunken, foaming flow of life, which in the joy of begetting carries living beings, is mysteriously identified with the dark water which throws the living into death" 20 .

For the will, the way to redemption now lies in artistic creation and play. Thus "even the ugly and the disharmonic are part of an artistic game that the will in the eternal amplitude of its pleasure plays with itself" (BT: 141). How do we understand this "eternal amplitude of pleasure"? From the perspective of its genesis, the best clue is provided by the analysis of the chorus as the matrix of the tragic vision in section 8. Nietzsche's central idea is that the Dionysian chorus "ever 
anew discharges itself in an Apollonian world of images. (...) In several successive discharges this primal ground of tragedy radiates this vision" (BT: 65). Since in order to generate this tragic vision the chorus must first identify with the will, this analysis can legitimately be applied to the will itself (which is also anthropomorphised by the reference to the Heraclitean child). The notion of a "discharge" suggests, in a pre-Freudian way, that the pleasure is generated by the release of tension in the artist (either human or cosmic) by means of the creative act, and thus as a form of sexual sublimation. From the onset, the Birth is ripe with sexual undertones - thus Apollo and Dionysus "coupled with each other, and through this coupling ultimately generated (...) Attic tragedy" (BT: 33). A later passage explicitly points the sexual undertones of Nietzsche's vision of the will: "Yes to life beyond all death and change: true life as the overall continuation of life through procreation, through the mysteries of sexuality"21. Bataille famously picked up on this aspect of Nietzsche's thought by defining eroticism as "the approbation of life even unto death" 22 , and the sexual act, whereby the "forms of regular, social life which ground the discontinuous order of the defined individualities which we are" 23 is dissolved, as an analogon of death. More generally, Bataille's analyses of transgression provide another useful clue to understand the ambivalent nature of the pleasure experienced by the will. Thus, the Theory of Religion describes the sacred as a squandering of energy which transgresses the rational, productivity-based economy of the everyday world. Similarly, the ontological creation and the destruction of worlds should be seen as an endlessly repeated sacrifice whereby the will constantly regenerates itself, its pleasure coming from the gratuitous excess of squandered forces (the "overflow of primordial delight" mentioned above).

At first sight, this second metaphysics does not seem bring any obvious change as far as human beings are concerned: our situation is now fairly close to the one evoked by Plato in the $\mathrm{Laws}^{24}$, which saw men as the frequently sacrificed "toys of the Gods", doomed to "spend their lives performing the most beautiful games according to this principle, and against their real inclinations" 25 . In what follows, I'll try to show that it does provide a way to solve the problem of redemption, both for the will and for human beings. But before turning to this, I want to examine the consequences of this metaphysical shift on the Apollonian and the Dionysian, and try to solve the difficulties previously noted. Remember that on Nietzsche's Schopenhauerian premises, his conception of the Apollonian was met with two difficulties: the first was that there was a contradiction between the main requirement for Apollonian contemplation (the shift from the empirical to the transcendental perspective) and its focus on phenomenal individuation. The second problem was that given the negative nature of individuation, neither the will nor human beings were likely to be redeemed by its glorification. We are now in a position to deal with both problems. We have seen that Nietzsche's second metaphysics departs from transcendental idealism and reverts to a view inspired by Heraclitus, in which the distinction between noumenon and phenomena is supplanted by the opposition between a creative principle (the will) and its productions (individuated entities). On this second reading, the difference between the will and individuals is not one of perspective (the will and the phenomenal world would be the same thing, considered either in itself or through the use of the principle of sufficient reason); it is one of nature, and refers to the ontological distance between the Demiurgos, the artisan of the world, and its creations. Correlatively, what is required of the artist is not a shift from the empirical to the transcendental standpoint, but an identification with the will's activity (not perspective) which analogically allows him to find a similar pleasure in the production and destruction of individuated images. Thus the very transcendental framework which made Nietzsche's definition of the Apollonian problematic becomes irrelevant. From the perspective of this return to a pre-critical metaphysics, it is now perfectly consistent for the Apollonian artist to focus on individuation; in fact, such a focus is required for the identification with the will's poietic activity to work in the first place. 
Remains the moral difficulty, i.e. the glorification of individuation as an evil principle. But individuation is now seen positively, as a pleasurable way for the will to discharge its primal tension and thus to find temporary fulfilment in the creation of individuated worlds. Transposed at the level of the human artist, and thus seen as a psychological state, the Apollonian performs an analogical task: it "lets us find delight in individuals; it attaches our pity to them and by means of them it satisfies our sense of beauty which longs for great and sublime forms" (BT: 128). The Apollonian relieves us of suffering by showing a heroic vision of individuation which makes human existence seem more beautiful than it really is: "so do the Gods justify the life of man: they themselves live it the only satisfactory theodicy! Existence under the bright sunshine of the Gods is regarded as desirable in itself, and the real pain of Homeric men is caused by parting from it, especially by the early parting" (BT: 43). As noted later by G. Lukacs in his Theory of the Novel26, the trademark of Homeric epics is that it simplifies the puzzling complexity of phenomena in order to provide us with attractively monolithic characters and simple, foundational narratives. Thus the Apollonian artist offers us maximised types of humanity: each of the Gods is defined by a main characteristic, of which it is the perfect embodiment (beauty for Aphrodite, a hot temper and warlike abilities for Ares, matronly qualities for Hera, etc ${ }^{27}$ ). Correlatively, the Apollonian artist generates the pleasurable illusion that the world is "universally intelligible" (BT: 35) for us, by contrast with "the incompletely intelligible everyday world". The paradigms of the Gods, light or dark, give us a model to understand our often conflictual emotions and lead our lives in a more purposeful way. They also provide us with a rationale for our existence (the heroes are often descended from divinities, which in turn legitimates their aspirations to rule $)^{28}$, and thus imbue us with a sense of our place in the universe, which "makes life possible and worth living" (BT: 35).

Two features in particular make the Apollonian transfiguration of individuation interesting: firstly, although it does not have a true content in the adequationist sense (not because individuation is not real, as in the Schopenhauerian picture, but because it is glorified), it is nevertheless true in that it is truthful. It does not pretend that the images shown are the real state of the world. The illusion must never be overwhelming: thus "even when this dream reality is most intense, we still have, glimmering through it, the sensation that it is mere appearance" (BT: 34), and there remains a "delicate boundary which the dream image must not overstep lest it have a pathological effect (in which case mere appearance would deceive us as if it were reality" (BT: 35). Secondly, the Apollonian does not present us with an overly sweetened vision of life in which the darker sides of existence would be erased out. The Iliad is rife with grim scenes and poignant descriptions ${ }^{29}$. Homer, the sublime "naïve artist" (BT 44), does not hide the pathos of Hector's and Andromache's suffering; there is no Hollywoodian pretense that things are fine, or that they will end well: "the serious, the troubled, the sad, the gloomy, the sudden restraints, the tricks of accident, anxious expectations, in short the whole divine comedy of life, including the inferno, also pass before him" (BT: 34-5). The pleasure generated by the Apollonian is of a paradoxical kind: it stems from an acute awareness of the precariousness of the human condition, combined with an epic transfiguration of human finitude whereby our ability to withstand these precarious conditions and morally rise above them is revealed. Thus there is a specifically Apollonian form of sublime, as opposed to the more well known Dionysian kind (the exceeding of subjectivity and the dissolution of self-awareness through the Masslösigkeit analysed by J. Sallis in Crossings), a sublime which paradoxically focuses on individuation, on form, and transfigures it from the inside.

Just as the creation of an individuated world brings pleasure to the will, in the same way the Apollonian production of epic images whereby finitude is transfigured brings us a bittersweet kind of pleasure whereby our existence is, at least temporarily, redeemed. In neither case is individuation the source of evil, quite on the contrary. What about the Dionysian, then? We have seen that Nietzsche's Schopenhauerian assumptions created two main problems: the first concerned the illusory nature of 
the Dionysian (which became unintelligible), and the second, its ambivalent characterisation as both painful and "the blissful ecstasy that wells from the innermost depths of man" (BT: 32). The first difficulty can easily be explained from the perspective of his second metaphysics: given that individuation is real, not the transcendentally ideal consequence of our use of the principle of sufficient reason, the communion with the will and its primary affects offered by the Dionysian can only be an illusion, whereby individuals, beholden to the "spell of such moods and insights (...) imagine that they are beholding themselves as restored geniuses of nature" 30 . The "surrendering of individuality" (BT: 64) remains symbolical in the sense that it is temporary, and does not involve the actual disappearance of the individual (hence the analogy with intoxication, and Nietzsche's repeated references to the "influence of the narcotic draught" (BT: 33)). Whereas the God was truly sacrificed, the Dionysian revellers only experience an imaginary death, which is also the reason why the Dionysian illusion is, as we shall see, paradoxically protective.

These characteristics are most clearly visible in the often overlooked Nietzschean distinction between the "barbarian" and the "Greek" forms of the Dionysian. In the more archaic, barbarian manifestations of the Dionysian, "the most savage instincts were unleashed, including even that horrible mixture of sensuality and cruelty which has always seemed to me the real "witches brew" (BT: 39). One may think of the Bacchae lovingly dismantling the body of Orpheus, or of queen Agave (mis)led by Dionysus to kill Pentheus, her husband, and unknowingly parading his head in the streets of Thebes. In both cases, the sacrifice is real, and accompanied by the sinking of the actors of the drama into animality (the "reversion of man to the tiger and the ape" (BT: 35) mentioned by Nietzsche). By contrast, with the "Dionysian orgies of the Greeks (...) for the first time the destruction of the principium individuationis becomes an artistic phenomenon" (BT: 40). This passage from the literal killing of the victim to the metaphorical death of the individual is expressed by the newly symbolic aspect of the Greek Dionysian: thus, "in the Dionysian dithyramb man is incited to the greatest exaltation of all his symbolic faculties. (...) The essence of nature is now to be expressed symbolically" (BT: 40). Contrary to the Apollonian artistic forms, which operate through the vision or the production of glorified images from which the poet keeps a distance, Dionysian symbolism works directly, through dramatic action. Thus the chorus, whose members "consider themselves and one another transformed" (BT: 64), re-experiences the fundamental duality of the will's affects, the fact that "pain begets joy, that ecstasy may wring sounds of agony from us" (BT: 36), and gives this duality a symbolic expression by means of dance, rhythmic moment, "music, dynamics and harmony" 31 (BT: 40), which all involve a taking over of the whole body. The "surrendering of individuality" generated by the "Dionysian excitement" is symbolical in that it is "a way of entering into another character", or again "to see oneself transformed before one's own eyes and to act as if one had actually entered another body, another character" (BT: 64). In doing so, the Greek Dionysian channels cosmic affects which would otherwise be too powerful for the individual and destroy him: thus the "horrible 'witches brew' of sensuality and cruelty [which was the characteristic of the barbarian Dionysian] becomes ineffective" (BT: 36). The only thing that remains of the primal Stimmungen of the will is "the curious blending and duality in the emotions of the Dionysian revellers", which stands to them as "medicines remind us of deadly poisons" (BT: 36). Thus the Greek Dionysian stands as a pharmakon, a source of intoxication, but also a symbolic shield against the more primitive forms of the Dionysian. Therefore, it is essential to the definition of the Dionysian that it should be illusory. The illusion does not come from the sublime glorification of individuation, as in the case of the Apollonian, but from another form of sublime, the symbolic annihilation of the individual, which allows the Dionysian actor to metaphorically re-live the God's agony and bliss. Correlatively, one of the reasons for the joyful character should also have become clear: insofar as its re-enacts the fundamental contradiction of the will, the Dionysian also repeats its affective tonality, which on Nietzsche's second metaphysics is both painful and pleasurable. 
However, this only accounts of the ambivalent aspect of the Dionysian, not for the overall joyful quality of the tragic. More generally, the fact is that although both illusions are protective, neither can on its own provide a full redemption. The distance which enables the Apollonian artist to project epic dream images also prevents him from fully experiencing the affects of the $U r$-Eine: he is a "close and willing observer" (BT: 34), but precisely for this reason he cannot truly identify with the creative force of the will. In Nietzsche's words, he « does not become fused with his images but, like a painter, sees them outside of himself as objects of contemplation » (BT: 64).Therefore Apollonian art, although beautiful, remains somehow existentially shallow in the sense that it is too reflective (hence the frailty of the illusion): it "presents images of life to us, and incites us to comprehend in thought the core of life they contain" (BT: 128), but this emphasis on intelligibility somehow kills the vitality of the images and tends to make them didactic (which is one of Lukacs' criticisms of epics).

Conversely, the Dionysian is not reflective enough: the symbolic identification with the will it generates has a purely affective content (the pleasure/pain duality), and works exclusively through unreflective action (thus the chorus is a "community of unconscious actors" (BT: 64)). These two characteristics make the experience of the Dionysian a totally enthralling one (contrary to the Apollonian, which as we have seen requires the "awareness of the dreamer"); but they also prevent it from becoming meaningful, and thus from having any lasting effects on human beings. Once freed from the Dionysian trance, the Dionysian reveller just reverts to his everyday self, and "Greek pessimism" is not durably overcome: thus "the rapture of the Dionysian state with its annihilation of the ordinary bounds and limits of existence contains, while it lasts, a lethargic element in which all personal experiences of the past become immersed. (...) But as soon as everyday reality re-enters consciousness, it is experienced as such, with nausea: as ascetic, will-negating mood is the fruit of these states" (BT: 59-60). For all its existential strength, the Dionysian does not, considered in isolation, have any real transforming or redemptive power.

Thus, although the above reconstruction provides better support to understand the Apollonian and the Dionysian, so far it has not provided a solution to the question of artistic redemption, to which I shall turn now. As far as the will is concerned, Nietzsche's artist's metaphysics puts us in a good position to account for the redemptive character of art. As we have seen, the idea of a cosmic play suggests various possibilities to understand the way in which suffering can generate and even be exceeded by pleasure (sublimation or Bataillean squandering of energy). In either case, the Schopenhauerian characterisation of the will's primary affect as pain is overcome by art, which changes radically the meaning of existence. Creation does not only provide sedation for the will: it generates the "indestructible and eternal" (BT: 104-5). "Infinite primordial joy in existence" analogically experienced by the human artist. In turn, this solves the motivational problem formerly evoked, as this "creative joy" becomes per se the incentive to life and legitimates the will's struggles. Thus the ultimate justification for life is not moral, but pragmatic. Thanks to art, the rewards of existence exceed its costs; the will is not noumenally doomed to endless suffering. Correlatively, the idea of an ontological poiesis allows Nietzsche to move away from the excessively Apollonian aspect of the previous picture of redemption. The production of individuated phenomena is not a dream of the will, it is real, and so is their annihilation. For the poietic sublimation of pain into pleasure to be effective, the affects unleashed, both in the creation and the destruction of individuals, must be fully experienced by the will, without the protective distance of the Apollonian self-awareness of the dreamer.

However, so far these arguments have not answered Julian Young's main objection to the Nietzschean picture of redemption, i.e. the fact that even if it were to work for the will, it would mean nothing to us. Why should we not succumb to pessimism, and how can art make our lives meaningful and worthwhile? Just as in the case of the will, the answer lies in Nietzsche's view of artistic creation. His fundamental intuition is that "what creates there [the will], what creates in an 
artistic way, acts within the artist himself" (KSA I: 7 [117], my italics). Or again, "the work of art (...) is a repetition of the originary process from which the world as emerged" (ibidem). The same, irresistible impulse to create is driving both the will and the artist : thus, "the will needs the artist, in whom the originary process is repeated" (KSA I: 7 [117]). Just as the will is able to transfigure pain into pleasure by means of the creative act, in the same way the artist can sublimate his own suffering through the production of the work ${ }^{32}$. Thus human art is the transposition of the will's ontological poiesis: "the creation by the artist is the imitation of nature in the deepest sense" (KSA I: 7 [196]), i.e. the imitation, not of the objects found in the natural world, nor even, in the Schopenhauerian sense of the ideas as the primary degrees of objectification of the will. What art imitates is the activity of a nature itself understood in the Greek sense, i.e. as physis, the fundamentally creative force at work in the universe, from which entities spring forward. In the poetic terms of the Birth, "be as I am! Amid the ceaseless flux of phenomena I am the eternally creative primordial mother" (BT: 104). If this identification is successful, then art equally provides the human artist and the will with a way to overcome suffering and make existence joyful, and worthwhile.

What still needs exploring, in order to give this notion of a human salvation its content, is the way in which the artist's "repetition of the originary process" works, which brings me to Nietzsche's thoughts about the tragic. Given the considerable amount of secondary literature on this question, I'll limit myself to the aspects particularly relevant to this study. Perhaps the first thing to say is that because of the ontological distance between the will and human beings introduced by Nietzsche's second metaphysics, tragic repetition can only be an analogical one. Otherwise, there would be an identity of nature, not only of activity, between the will and the human artist - a claim that his early metaphysics prevents Nietzsche from making. This is why, in the Birth, both the Apollonian and the Dionysian must be illusions, and the artist's identification with the will must remain analogical (hence the many references to dream and intoxication). Among the many passages describing this analogy, the following is perhaps the clearest: "In the first place, as a Dionysian artist [the lyricist] has identified himself with the primal unity, its pain and contradiction. (...) He produces the copy of this primal unity as music. Now, however, under the Apollonian dream inspiration, this music reveals itself to him again as a symbolic dream image (...), a specific symbol or example" (BT: 49). The Dionysian illusion (the symbolic dissolution of individuation) allows for the first step, while its Apollonian counterpart (the projection of a beautiful dream image, whereby the artwork is generated) completes the process. The reason why the first symbolisation is musical is that as we have seen, the Dionysian identification with the will works by enabling the artist to re-experience directly its primal affects, and Nietzsche follows Schopenhauer in understanding music in an expressionist way, as a "primary and universal" 33 translation of emotions. As it "stands in symbolic relation to the primordial contradiction (...) in the heart of the primordial unity" (BT: 55), the flow of music communicates immediately the nuances and intensity of the fluctuating Dionysian affects (the best example of this symbolisation of the primal contradiction being for Nietzsche the pleasurable/painful quality of dissonance). In doing so, music gives Apollonian images a depth that they couldn't achieve on their own, and "allows the symbolic image to emerge in its highest significance" (BT 103). Thus "[the harmonies of drama and music] make the relations of things immediately perceptible to us in a sensuous, by no means abstract manner, and thus we perceive that it is only in these relations that the essence of a character (...) is revealed clearly" (BT: 128) ${ }^{34}$. Conversely, the Apollonian "examples" confer to music a clarity of meaning which it wouldn't have on its own: they bring some articulacy to the Dionysian emotions, which in turns strengthens the aesthetic experience by allowing for finer distinctions between the affects: "the drama, with the aid of music, unfolds itself before us with such inwardly illuminated distinctness in all its movements and figures, as if we saw the texture coming into being on the loom as the shuttle flies to and fro" (BT: 130). Therefore the tragic artist, by identifying with the will's pathos and activity (the Dionysian illusion), recreates its primary 
Stimmungen; but by combining them with Apollonian clarity, he gives us in his work a way not only to experience the will's transmutation of its primary affects, but also to understand that through this creative process, suffering is redeemed and life becomes worthwhile. One "shudders at the sufferings which will befall the hero and yet anticipates in them a higher, much more overpowering joy" (BT 131). While the effects of the Dionysian become much more long-lasting, Apollonian intelligibility in turn acquires a metaphysical content that it could never achieve on its own. This content is the "metaphysical comfort" (BT: 59. See also 62 and 104) of tragedy, the idea that even when "forced to look into the terrors of the individual existence, yet we are not to become rigid with fear" (BT: 1045), because we can still "become one with the infinite primordial joy of existence" 35 (BT 105).

It thus appears that the key to answering Young's criticism is to focus on the idea that salvation lies in artistic creation, not in contemplation, and this, both for the will and the individual. In Nietzschean terms, one must embrace the perspective of the creator, not that of the spectator, a point that the Birth makes explicitly in its analysis of the chorus ${ }^{36}$. This shift constitutes a radical break from the Schopenhauerian aesthetics still presupposed by Young's version of salvation, in which the will was just the dreamy spectator of the human struggles. What is required for artistic redemption to work is identification of the artist (or of the spectator, through the influence of the work) with the will in its creative power - therefore, an identification with the chorus, not with the hero of tragedy, as it is usually claimed. Just as the chorus, in its "successive discharges", frees itself from suffering, in the same way the artist can sublimate the pain of existing by means of the creation of the work. The reason why Young fails to understand the redemptive power of human art is that he implicitly accepts the Schopenhauerian idea that redemption should be equated with an absence of pain. The rationale for renunciation, in book IV of WWR, is indeed that since existence is noumenally doomed to endless suffering, the only consistent attitude for the will is to negate itself. Although Schopenhauer insists that avoidance of pain is not the primary motivation for such a renunciation (which is called for on logical grounds), his final apology of nothingness shows clearly that for him, the ideal state is one in which nothing is felt, neither pleasure nor pain ${ }^{37}$. By contrast, in the Birth true salvation lies in our willingly accepting pain and finding the strength, not only to bear it passively, but to actively transmute it into pleasure through artistic creation. Both the individual and the will must accept the fact that this transmutation of pain into pleasure is not a permanent result, and that the creative process must endlessly be repeated. Properly understood, early Nietzsche's metaphysics thus shows us that although life may seem to the uncreative individual a vale of suffering, its overall meaning is positive as suffering can be overcome through art. This is perhaps the most radical way in which the Birth departs from Schopenhauer, anticipating strikingly later themes in Nietzsche's thought, in particular that of artistic sublimation in Twilight of the Idols and of amor fati as a heroic endorsement of finitude (as opposed to the Schopenhauerian flight beyond the human condition). As we shall see, understanding the redemptive function of this metaphysics properly also has important consequences for the question of its status, to which I shall now turn.

A survey of the considerable literature devoted to this topic shows that commentators have focused on and implicitly linked two questions: 1) whether Nietzsche did believe in the metaphysical claims he put forward in the Birth and 2) if not, how we should view this metaphysics — in particular, whether it should be seen as a myth, and in which sense. Depending on the answer to these questions, a normative judgment is issued regarding the value of Nietzsche's early metaphysics. In reaction to interpretations such as Kaufmann's (Kaufmann: 1974), which took the Birth literally and assumed that early Nietzsche had an uncritical stance towards its claims, more recent works have tended to answer 1) negatively, 2) positively and to conclude from the conjunction of the two answers that the metaphysics should be discarded. Before putting forward my own interpretative claims, and in order to recontextualise them, I have chosen to examine two of the most notable interpretations, namely Porter's and Poellner's. 
Porter's fairly influential reading, following De Man, asserts that "it is not even a foregone conclusion that Nietzsche himself believed, or needed to believe, whatever he wrote" (Porter: 2000, 29). Arguing from the influence of Lange's Geschichte des Materialismus on Nietzsche's early thought and from his 1868 essay on Schopenhauer, in which the latter is strongly criticised for having forgotten the Kantian prohibition about the unknowability of things-in-themselves and thus relapsed into dogmatic metaphysics by attributing to the will qualities which can only pertain to phenomena, Porter concludes that "Nietzsche's book seems to project a myth drawn with deliberate perspectival distortion" (Porter: 2000, 157). Porter's reading is deconstructionist in that he thinks that the ultimate purpose of such a projection is to undermine both the possibility of metaphysical thinking and of myth, by launching "an inexorable attack on the credibility of all myths. Here we detect a sense of strain, of extremity: plausibility is taxed, myths counteract myths and all but cancel each other out in an overwhelming dubiety" (Porter: 2000,148). There are, however, serious problems with Porter's reading. The first is methodological and consists in his tendency to proceed from post-modern assumptions for which he offers no justification: thus, he claims that "Nietzsche has no philosophy in the proper senses of 'having' and of 'philosophy'. This is an argument that can only be suggested here" (Porter: 2000, 4). This lack of argumentation, already problematic given the importance of the claim and its consequences on interpretative strategies, is compounded by the absence of any definition of what "proper" philosophy, or the possession of it, might amount to. Perhaps as an indirect answer to this, Porter asserts in a footnote (again without any demonstration) that "Nietzsche attacks philosophical presuppositions, without making any truth claims of his own" (Porter: 2000, 184). Not only is it difficult to see how Nietzsche could do so and say anything of philosophical relevance about the criticised presuppositions - it might be more profitable, as Poellner suggests elsewhere (Poellner, 1995, $13 \mathrm{sq}$ ) to read his work, especially in his mature period, as an attempt to methodically refute metaphysical conceptions of truth, which is not tantamount to rejecting all claims to truth; moreover, many passages from the Birth make it clear that Nietzsche does make some claims to truth (for example, in asserting that life has a "true, i.e. metaphysical significance" (BT: 136, my italics), or that "we shall have gained much for the science of aesthetics, once we perceive (...) that the continuous development of art is bound up with the Apollonian and the Dionysian duality" (BT, §1, 33, my italics).

The second problem with Porter's interpretation (perhaps a consequence from his assumption that Nietzsche makes no truth claims of his own, which removes the need to examine the content of his assertions too closely, or to reconstruct his thought in as coherent a way as possible) is that it is often mistaken. Perhaps the most damaging instance, given his interpretation, is the claim that the Birth aims at destroying mythical thought, which flies in the face of textual evidence (see BT: $\S 23,136$, to which I shall come back in detail). But there are other examples, in particular the following argument offered in favour of the paradoxical thesis that the Dionysian is "the invention of the Apollonian" (Porter: 2000, 49): "the conditions of possibility of the Dionysian principle are located within the realm of appearances (...). The metaphysical is a pleat within the surface of appearances" (ibidem). This argument rests on an implicit confusion between conditions of existence and conditions of intelligibility. As we have seen, all that can be concluded from Nietzsche's analysis of the relation between the Apollonian and the Dionysian is that in the case of tragedy, the second is dependent on the first in order to be understood as such (as opposed to simply being experienced). There is no indication that the existence of the Dionysian is dependent on that of the Apollonian (on the contrary, Nietzsche insists on the anteriority, both chronological and ontological, of the former over the latter). And if the Dionysian is to be understood as a metaphysical principle (as suggested by the last sentence of the quote), then the claim is equally mistaken as the existence of the thing-initself is by definition independent from the conditions which make it phenomenally accessible to finite beings (only an intuitus originarius would create the object of its intuition in the process of 
intuiting it $)^{38}$. Because of its methodological problems and inaccuracies, Porter's reading, although suggestive, thus remains in my view of little philosophical interest.

I shall now turn to Poellner's interpretation of the Birth's metaphysics, which is considerably more rigorous and philosophically grounded. Although his approach to Nietzsche is radically different — in another work, he dubs himself a "reconstructionist" (Poellner: 1995, 10), a label under which my own endeavour probably falls - Poellner's earlier article on the Birth has in common with Porter's book that he too answers 1) negatively and 2) positively ${ }^{39}$. Thus "there can be no doubt that [Nietzsche] considered [this artist's metaphysics] arbitrary, logically arbitrary, even at the time of writing it" (Poellner: 1998, 67). Yet contrary to Porter, Poellner (rightfully) sees Nietzsche's attitude to myth as serious and positive: "what he did not consider arbitrary or fantastic, and certainly not futile, was the general (...) schema this metaphysics exemplifies or satisfies. This is the schema of myth in the second sense I indicated earlier" (Poellner: 1995, 67-68). Poellner is careful to distinguish three meanings for the notion of myth: i) « a story or image which connects the temporal flux of appearances to an underlying ontological ground and which presents that ground (...) as not, or not fully, accessible to rational explanation (Poellner: 1995, 64), ii) "a narrative relating transient human experiences to a purposeful, time-transcending order of reality" (ibidem) and iii) "myth as an illusory or erroneous, i.e. false, story — as Illusion, or Wahn (ibidem). Meanings i) and ii) both presuppose the metaphysical distinction between two orders of reality and work in opposite but complementary directions: while the first is focused on presenting the ontological ground through appearances, the second relates appearances to the ground and thus reveals their true meaning while transfiguring the everyday. Poellner grounds this reading of myth in an important passage of the Birth which states that "any people — just as, incidentally, any individual — is worth only as much as it is able to press upon its experiences the stamp of the eternal; for thus it is, as it were, de-secularised and shows its unconscious inward convictions of the relativity of time and of the true, i.e. metaphysical, significance of life" (BT: §23, 136). For from being bent on undermining mythical thought, Nietzsche would thus have put forward both the Birth's Artisten Metaphysik and the teleological narrative heralding the revival of the Dionysian through such works as Schopenhauer's or Wagner's as "second order myths" (the first order myth being the reconstruction of the "tragic myth of the pre-socratics", Poellner: 1995, 65) meant to counterbalance the effects of Socratism and to revitalise German culture. Poellner then turns to the question of whether the metaphysics can truly play this role, or whether it should be seen as a myth in the third sense, i.e. as an error or illusion ${ }^{40}$. His answer takes the form of the following argument: a) the myth is supposed to transfigure appearances by expressing the "true, i.e. metaphysical significance of life". Yet b) the latter is encapsulated by the "Schopenhauerian wisdom of Silenus which Nietzsche, without any doubt, continues to accept" (Poellner: 1995, 67), and according to which "existence is 'terrible' and 'horrific"' (ibidem). Given this content, it is difficult to see how the myth could perform its redemptive role. Therefore c) Nietzsche is caught in a no-win situation: to avoid the contradiction, the myth must be seen as an illusion. Yet if it is known to be illusory, then it loses the power to "motivate the (...) transfigurative project of BT" (Poellner, 1995, 67) ${ }^{41}$, and thus cannot function as a myth in the Nietzschean sense. Poellner logically concludes that "Nietzsche's abandonment of [his early] philosophy is perhaps most fruitfully interpreted as the consequence of his realisation of this aporia" (Poellner: 1995, 75).

Although I have great sympathy for Poellner's argumentative and rigorous approach and agree with his view that the Birth should be seen as "mythopoietical" (although for reasons of my own, cf. below), I must disagree with his final criticism. Two things should be noted: firstly, he offers no direct argument for the claim that "there is no doubt that [Nietzsche] considered [this artist's metaphysics] arbitrary, logically arbitrary". The assertion can be seen to follow both from Poellner's summary, in the first part of his paper, of Nietzsche's early essay on Schopenhauer, and from the 
argument outlined above. Yet the latter does not show that Nietzsche did not believe in the metaphysics, only that if he did so, he would have ended up in an inconsistent position. But he may well have done so without being aware of it - as could be hinted at by the "Attempt at SelfCriticism"'s well known assertion that the book was "constructed of a lot of immature, overgreen personal experiences" (BT: 18), which doesn't suggest that the young Nietzsche had much self-critical distance at the time. Secondly, and more importantly, there are reasons to believe that the inconsistency underlined by Poellner results from an interpretative mistake about the "true" meaning of life. Strangely enough given that his interpretation of the Birth is bent on highlighting the theoretical rift between early Nietzsche and Schopenhauer, Poellner asserts that the Schopenhauerian view that existence is "terrible" remains Nietzsche's "unquestioned presupposition in the Birth"(Poellner: 67). By contrast, and from my own reconstruction as outlined in the preceding pages, I would argue that it is only his starting point. as we have seen, what the metaphysics shows us is that the true meaning of existence, both for the will and for us (pace Young), resides in the overcoming of pain by pleasure through artistic creation. It teaches us that far from being "horrific", "life is at the bottom of things, despite all the changes of appearances, indestructibly powerful and pleasurable" (BT: §7, 59). The aesthetic process, which is instantiated both noumenally (in the will's constant creation of "worlds") and phenomenally (actively, through artistic creation, or more passively, through our identification with the chorus in the case of tragedy) provides the purposiveness that Schopenhauer wrongly denied both the will (as a blind, mindless principle) and human existence, and from which the terrors of existence stem. Through Nietzsche's aesthetic theodicy ${ }^{42}$ pain and suffering are not denied reality (as was often the case in earlier theodicies) but become meaningful as part of the process of creation whereby the will is "continuously redeemed" (BT: $\S 4,45)$. The main difference between us and the will, then, and the reason why for some people existence can be experienced as fundamentally horrible, is that while the will is constantly creative (and thus continuously overcomes its pain), we, as finite beings, are not so. Artists are limited by physiology in their ability to respond to and channel stimuli; moreover, it is possible, especially in a decadent age such as the one Nietzsche describes, that many individuals' artistic potential may have atrophied (although Nietzsche's optimism in the Birth suggests that it never disappears entirely). This means that while for the will the meaning of existence is overwhelmingly positive, for us the recognition of the positive metaphysical significance of life, although always possible in principle, can take the form of a struggle (hence the perceived need for redemption). We have to learn the crucial importance of artistic creation, and also to acquire the distance and skill required to balance the creative moments, in which pain is transmuted into pleasure, with other times at which suffering may seem predominant (hence the above examined need for an interaction between the Dionysian and the Apollonian). However, no matter how difficult the metaphysical truth may be for us to see, the main point here is that the premise held to by Poellner in b) is wrong, which in turn invalidates the conclusion expressed in c). There is no contradiction between the content of the myth and its function, and therefore no need to see the latter as an illusion (in the sense of a false narrative) or to worry about its motivational power. Since the Birth shows that contrary to appearances, existence is pleasurable, it is perfectly consistent for Nietzsche to claim that his metaphysics can play a mythical and transfigurative role in revealing the true meaning of life. Correlatively, the potential contradiction between i) the claim that existence is fundamentally pleasurable and ii) the idea that it would still need to be redeemed is easily avoided if one takes into account that it is pain, not existence, which needs to be redeemed, and that the process whereby this happens and pain is transmuted into pleasure encapsulates the true, overall meaning of life. Existence itself (like becoming) is "innocent". Moreover, it is only from the unenlightened perspective of the non creative individuals (whom the Birth has to convince) that such redemption is necessary. From Nietzsche's 
own perspective, the problem is not to redeem existence but to recognise its true meaning and to find the proper medium to communicate it ${ }^{43}$.

However, this does not address Poellner's other, more implicit point, namely the idea that given his criticism of Schopenhauer, it would make little sense for Nietzsche to do exactly what he accuses the latter of doing, i.e. to "drape an altogether dark incomprehensible $\mathrm{X}$ with predicates taken from a world foreign to it, the phenomenal world, like colourful clothes" (S, 357). With respect to this issue, perhaps the first thing to note is that in the few passages in which Nietzsche reflects on the Birth's metaphysics, he is careful to present it as an assumption (Annahme): thus "the more clearly I perceive in nature those omnipotent art impulses (...), the more I feel myself impelled to the metaphysical assumption that the truly existent primal unity..." (BT: $\S 4,45$, my italics). Another passage is equally cautious in suggesting that "we may assume that we are merely images and artistic projections of the true author..." (BT: §5, 52, my italics). This is perfectly consistent with the Kantian prohibition against attributing any phenomenal predicates to the thing-in-itself (as is the idea that we are "impelled" to make metaphysical assumptions, which seems to echo Kant's own reflections about the "tendency of [pure reason's] nature" to reach beyond experience in the "Canon of Pure Reason" ${ }^{44}$ ). Of course, the question then arises of why Nietzsche should feel impelled to make this particular assumption (rather than other, perhaps more plausible ones), and of whether his cautiousness results in depriving his metaphysics - which, following up on the reference to Kant, would then have to be considered, at best, as an idea of pure reason - of any claim to truth, and thus of any theoretical strength. As one can imagine, both parts of the question are difficult to answer: for lack of space, I shall confine myself to a brief sketch of what I take Nietzsche's views to be on these issues.

Perhaps the best way to approach the question is negatively, by pointing out that for early Nietzsche all forms of knowledge, and not only metaphysical knowledge, reflect the conditions under which they are formed and are thus deemed illusory (in the sense that they fail to grasp the state of the world as it is independently of any observer): "today philosophy can only underline the relative character of all knowledge, its anthropomorphism, as well as the everywhere sovereign force of illusion" (KSA III: 19 [37], Nietzsche's italics). Nietzsche's reasons for thinking so are twofold, and can be seen as (non Kantian) developments of the analyses of the conditions of possibility of knowledge put forward in the "Transcendental Aesthetics" and in the "Analytic of Judgment". Firstly, the transcendental forms of perception, namely time and space, are subjective (in the sense of being relative to us as perceiving beings) and thus fail to capture the real essence of things ${ }^{45}$. Secondly, knowledge is by definition conceptual, and concepts are arbitrary: "our understanding is a surface force, it is superficial. It knows by concepts (...). At the end of the day, it is thus something which refers to man's arbitrariness, and does not reach the thing itself' (KSA III: 19 [66], Nietzsche's italics). This reasoning rests on the claim, made elsewhere, that concepts are second-order ways of relating to the world, and that the first order manner (from which they derive), namely perception, is itself arbitrary ${ }^{46}$. The two lines of argument can be seen to converge in the following passage: "When an entity, for example a tree, appears to us as a multiplicity of properties, of relations, there is a double anthropomorphism: firstly, this "tree" does not exist as a separate entity, it is arbitrary to carve an object in this way (according to eye, form), and secondly each relation is not the true absolute relation, but is in turn tainted with anthropomorphism" (KSA III: 19 [236]). Although he starts from Kantian premises, Nietzsche thus arrives at the thoroughly anti-Kantian conclusion that "nature has installed man in the midst of illusion. This is his specific element" (KSA III: 19 [179]), or again that "one must establish this principle: we only live through illusions - our consciousness only touches the surface" (KSA III: 19 [48]). I shall (regretfully) leave aside the question of whether such phenomenalism is justified ${ }^{47}$ to focus on its consequences for Nietzsche's view of metaphysics and myth. 
Early Nietzsche's radical skepticism about the possibility of true knowledge has three main implications. Firstly, since all knowledge is illusory there is no standpoint available to us from which the "fantastical" content of the Birth's metaphysics can be criticised as particularly ungrounded (although, by the same token, it is equally impossible to show that it is right ${ }^{48}$ ): to say that it is "illusory", as Poellner does, is not an objection which would carry great weight on Nietzsche's terms. Secondly (and consequently), whatever reason one may have to endorse its content must not rely on its truth value, but on other considerations. Thirdly, the role of the philosopher (and thus Nietzsche's own role) has to be redefined: it is not to establish truth but to "help to live", to "demonstrate the necessity of illusion, of art and of art dominating life" (KSA III: 19 [36]). Another passage is even clearer: "[The philosopher] feels in a tragic way the fact that the ground of metaphysics has withdrawn, and yet cannot be satisfied with the kaleidoscopic play of the sciences. He works towards the edification of a new life: he gives art its rights back" (KSA III: 19 [35], Nietzsche's italics). It is on this background that both Nietzsche's metaphysics and his reflections on myth should be understood. Indeed, given the above criticism of knowledge and his attack on Schopenhauer, it is unlikely that Nietzsche regarded the metaphysics as literally true (in the adequationist sense of offering an exact representation of the way things are in themselves), and thus I find myself inclined to agree with Poellner that he saw it as a myth. Apart from the passage of the Birth quoted by Poellner, there is evidence for this in the Nachlass, which characterises philosophical activity as "poetic invention outside of the limits of experience, a prolongation of the mythical instinct [which] also works essentially by images" (KSA III: 19 [63], my italics). However, this does not mean that Nietzsche viewed the Birth's metaphysics as inconsistent, or as illusory in the sense of being particularly deceptive. As we have seen, there is no contradiction between the content of the metaphysics and its transfigurative function. Moreover, one could argue that the metaphysics' openly "fantastical" character makes it more truthful (although no truer in the metaphysical sense) than the rationalist discourses criticised by Nietzsche, which hide their illusory nature behind scientific forms. It doesn't mean either that Nietzsche saw the metaphysics as 'rationally arbitrary filling in' of the schema of myth (Poellner: 67). It is arbitrary in the above examined sense that all knowledge is arbitrary; but if one shifts from an epistemological to an ethical perspective, then there is nothing arbitrary about the "filling in" of the schema. The content of the metaphysics is chosen for its particular usefulness for life (or in the terms of the Birth for its "healing" power), which is not an irrational choice. This concern for the revival of German culture also governs the choice of the form of the metaphysics: its mythical character, which involves a heavy reliance on metaphors and images, enables it to work as an art form ${ }^{49}$, and thus to counterbalance the deleterious effects of Socratism on modernity. Following "existentialist" interpretations of myth such as Bultmann's ${ }^{50}$, I would thus suggest that Nietzsche intended the metaphysics, not as an explanatory device nor as a literal representation of the real state of affairs in the world, but as a symbolisation of the meaning of life $\mathrm{e}^{51}$, belief in which is pragmatically justified by its potentially positive effects on us. To say that the metaphysics is symbolical means that Nietzsche did not require us (nor himself) to believe in its literal content, but to be able both to appreciate its images aesthetically and to extract their existential meaning, which is enriched from being embodied in the images. This calls for a change of attitude from the part of the reader, who must bracket his "historical sense" so that he can accept the myth as a "concentrated image of the world that, as a condensation of phenomena, cannot dispense with miracles" (BT: §23, 135] and, by understanding the part played by artistic creation in the metaphysics, feel its revitalising benefits ${ }^{52}$.

Provided it is carefully reconstructed and pried out from Schopenhauer's, the Birth's metaphysics does not display the kind of inconsistency or contradictoriness for which it is often indicted. If it is to be seen as a myth, it is not by default (i.e. as opposed to "true" knowledge, which 
early Nietzsche deems unattainable anyway) but because in a world of illusions, only myth has the power to counterbalance the degenerescence of contemporary culture. However two difficulties remain: the first pertains to the pragmatic argument suggested above, according to which the main reason to believe in the artist's metaphysics is that it is helpful for life. It could be objected that for one to be able to feel the healing power of the myth (and thus to be sensitive to the pragmatic justification for belief) one must already believe in it, and thus have effected the existential transformation that the myth is supposed to help perform. As we have seen, mere intellectual consideration of myths deprives them of their power. While it is not contradictory for the initiated to believe in a myth knowing that it's a myth (because the symbolisation performed by myths relies on the implicit claim that although the mythical narrative may seem ungrounded from an empirical perspective, it presents a correct symbolisation of the ontological state of affairs), it is almost impossible to be convinced by one unless we already have had the kind of experience symbolically conveyed by the myth, in which case the myth is not truly needed. Given this, it may seem that in offering his metaphysics to us decadents as a mythical remedy against Socratism, Nietzsche is begging the question. Artists won't need it, and theoretical men won't be convinced by it ${ }^{53}$.

Secondly, there is the problem of justification for Nietzsche's own belief in the symbolical value of the myth. While it seems clear that he cannot have believed the metaphysics to be literally true, he certainly did think that its symbolical meaning has real truth content - in particular, the belief that artistic creation is the only desirable way to overcome pain was retained throughout his philosophical career. This is entailed by his very definition of the mythical ability of a people as showing the latter's "unconscious inward convictions of the relativity of time and of the true, i.e. metaphysical, significance of life" (BT: §23, 136, my italics). Myth presupposes by definition the distinction between two orders of reality and the possibility of an adequate symbolic presentation (although not rational knowledge) of the ontological ground. While the distinction itself is not a problem for early Nietzsche ${ }^{54}$ and is in fact required by the Kantian premises that govern his criticism of knowledge, the second is problematic, for it is difficult to see how the symbolisation could be pronounced adequate without breaching the Kantian prohibition Nietzsche still adheres to ${ }^{55}$. Perhaps significantly, Nietzsche does not offer any criteria, and describes the way his belief was acquired as the "immediate certainty of vision" (BT: $\S 1,33$ ). Yet given that one of the main reasons why Nietzsche criticised Schopenhauer in his early essay was precisely because the latter resorted to the notion of an immediate, non representational intuition (in book II of WWR) to bypass the Kantian prohibition, it seems strange to see Nietzsche himself appealing to an intuition of the same kind. It thus seems that while Nietzsche forcefully denied the possibility for us to attain metaphysical truth (as correspondence between the view expressed by a statement and the state of things as they are independently of us), either by rational or by intuitive means, his very belief in the symbolical content of the metaphysics as myth still relies on it. 


\section{LIST OF ABBREVIATIONS:}

a) For Nietzsche's works (by chronological order of the original, German publications)

S: "Zu Schopenhauer", in Werke. Historisch-Kritische Gesammtausgabe, eds H. J. Mette and K. Schlechta, Munich, 1933ff, III, 352-361.

BT: The Birth of Tragedy (trans. W. Kaufmann, New York: Vintage books, 1967).

KSA: Nachgelassene Fragmente (Herbst 1869 bis Herbst 1872), Berlin: Walter de Gruyter, 1978).

GS: Gay Science, (trans. W. Kaufmann, New York : Vintage books, 1974).

BGE: Beyond Good and Evil, (trans W. Kaufmann, New York : Vintage books, 1989).

TI: Twilight of the Idols, (trans. R. Polt, Hackett publishing: Indianapolis, 1997).

WP: The Will to Power, (trans. W Kaufmann, New York : Vintage books, 1968)

b) For Schopenhauer's works

WWR: The World as Will and Representation, (transl. E.F.J. Payne, New York: Dover publications, 1958). Volume I contains the original text, and volume II the Supplements. 


\section{LIST OF AUTHORS}

Bataille, G (1957), L'érotisme. Paris: Editions de Minuit.

(1974), Théorie de la religion. Paris : Gallimard.

Bultmann, R (1953), "New Testament and Mythology", in Kerygma and Myth, Hans-Werner Bartsch ed., London.

Clarke, M (1990), Nietzsche on Truth and Philosophy, Cambridge.

De Man, P (1979), Allegories of Reading, New Haven \& London.

Fink, E (1982), Spiel as Welt Symbol, Kohlhammer, Stgt (no English translation).

Haar, M (1996), Nietzsche and Metaphysics. Albany : State University of New York Press.

Homer (1950), Iliad. Harmondsworth, Eng. : Penguin Books.

Kaufmann, W (1974), Nietzsche: Philosopher, Psychologist, Antichrist, Princeton: Princeton UP. Lukacs, G (1971), The Theory of the Novel: a Historico-Philosophical Essay on the Forms of Great Epic Literature. London: Merlin Press.

Nussbaum, M (1998), in Salim Kemal, Ivan Gaskell, Daniel W. Conway (eds.) Nietzsche, Philosophy and the Arts, Cambridge : Cambridge University Press.

Poellner, (1995), Nietzsche and Metaphysics, Oxford: Clarendon Press.

(1998), "Myth, Art and Illusion in Nietzsche", in Myth and the Making of Modernity. The

Problem of Grounding in Early Twentieth-Century Literature, M. Bell and P. Poellner eds,

Amsterdam - Atlanta: Rodopi.

Porter, J (2000), The Invention of Dionysus: An Essay on the Birth of Tragedy, Stanford: Stanford UP. Richir, M (1998), La Naissance des Dieux. Paris: Editions du Seuil, collection "Points".

Sallis, J (1991), Nietzsche and the Space of Tragedy. Chicago: University of Chicago Press.

Young, J (2001), Nietzsche's Philosophy of Art. Cambridge: Cambridge University Press.

\footnotetext{
${ }^{1}$ in particular in his 1886 « Attempt at Self Criticism », published in BT, §2, p. 18.

${ }^{2}$ See for example (by chronological order): G. Deleuze, Nietzsche and Philosophy, London: Athlone Press, 1983, especially section 5, "The Problem of Tragedy", p. 11: "if one looks at the Birth of Tragedy it is clear that Nietzsche wrote it (...) as a disciple of Schopenhauer"; R. Schacht, Nietzsche, London: Routledge, 1992, in particular section VIII, "Art and Artists" p. 478: "Nietzsche makes no attempt to conceal the influence of Schopenhauer on both his concept of reality and his thinking about the arts in The Birth of Tragedy. He was initially convinced of the soundness of much of what Schopenhauer had to say about the world, life and art". Like Young, Schacht develops the view that while early Nietzsche disagreed with Schopenhauer on the function of art, he "does not question the soundness of this picture [i.e.: the Schopenhauerian metaphysics briefly outlined by Schacht]. And even though he later rejected Schopenhauer's metaphysics, which he here accepts..." (p. 479). See also M. Nussbaum (1998), in Salim Kemal, Ivan Gaskell, Daniel W. Conway (eds.) Nietzsche, Philosophy and the Arts, Cambridge : Cambridge University Press 1998, and R. J. Hollingdale, Nietzsche: The Man and His Philosophy, Cambridge: Cambridge UP, 2001, in particular chapter 5, pp. 66: "in his first enthusiasm, Nietzsche accepted Schopenhauer tout court" and 70: "Nietzsche took over Schopenhauerian dualism in his early philosophy”. There are, however, exceptions, in particular Michel Haar's Nietzsche and Metaphysics, Albany : State University of New York Press, 1996 and more recently, Peter Poellner's paper, "Myth, Art and Illusion in Nietzsche" (in Myth and the Making of Modernity: The Problem of Grounding in Early Twentieth Century Literature, ed. Michael Bell and P. Poellner, Amsterdam-Atlanta: Rodopi, 1998, p. 61-80. Haar's reading is substantially different from mine in that he holds that even at the time of the Birth, Nietzsche had already abandoned the distinction between the thing-in-itself and appearances, a claim which, as the third part of this paper will suggest, is false. There are more affinities between the Poellner's reading of BT and mine (in particular concerning early Nietzsche's distance from Schopenhauer, the question of the illusory nature of both the Apollonian and the Dionysian, and the emphasis on the poietic activity of the will). However there are also substantial differences which will be examined in the third part of this paper.
} 
${ }^{3}$ Ibidem. Young also thinks that Nietzsche never really moved away from Schopenhauer.

${ }^{4}$ It is worth mentioning that for Schopenhauer himself the status of individuation is highly ambiguous, although this ambiguity remains implicit throughout WWR. Thus, Book I follows Kant in seeing individuation as transcendentally ideal (because it is the correlate of the necessity for us to perceive through the a priori framework of time, space and with the use of causality) but empirically real (hence the possibility for such sciences as physics, to which Schopenhauer devotes a whole chapter, to state meaningful and true propositions). But in book III, Schopenhauer tries (unsuccessfully) to combine transcendental idealism and Platonism, by introducing the notion of the ideas as the primary degrees of objectification of the will. These ideas are seen as eternal and unchanging beings, as archetypes the perception of which is obscured in the phenomenal world; correlatively, the principle of sufficient reason is redefined as an illusory principle, the veil of Maya, which hides from us the true nature of the ideas (and of the will). On this second view, individuation becomes empirically ideal, a position which obviously conflicts with Schopenhauer's former Kantian premises.

${ }^{5}$ All translations are mine; see also 7 [153].

${ }^{6}$ See also 7 [166], « the originary One is identical with pain ».

${ }^{7}$ Correlatively, the principle of sufficient reason is redefined as the delusory "veil of Maya", a move which implicitly collapses the difference between Erscheinung and Schein and generates severe difficulties for Schopenhauer's version of transcendental idealism.

${ }^{8} \mathrm{~J}$. Young claims (p. 33) that the objects of Apollonian contemplation are "modeled upon Schopenhauer's Platonic ideas". However this claim is partially dependent on Young's phenomenological interpretation of the ideas in WWR, which I don't find conclusive enough. Moreover, even on his interpretation the difficulty would remain as in the examples he gives, individuation is still achieved by means of the use of the principle of sufficient reason, which is contradictory with the requirement of a shift to the transcendental standpoint. ${ }^{9}$ This is made explicit by the subtitle of book III of WWR.

${ }^{10}$ Nietzsche's reference to Hamlet in the same passage is directly inspired by Schopenhauer, who in the chapter of the Supplements devoted to tragedy used the same paradigm (along with that of Marguerite in Goethe's Faust) to describe the burning out of the desire to live in the individuals who, through an excess of suffering, have seen beyond appearances, into the noumenal nature of the will, and thus lost the impetus to perpetrate the phenomenal contradiction through their actions.

${ }^{11}$ Mainly excessive suffering, or the painful realization by the ascetic that he is one with the world.

${ }^{12}$ John Sallis' Crossings is a good example of this tendency.

${ }^{13}$ See also BT: 50.

${ }^{14}$ Although Young does not say so, this claim, again, partially rests on Schopenhauerian assumptions. In WWR, the function of genius is to provide the will with a "mirror" in which it can both find some respite from the torments of the phenomenal world, and achieve the self-consciousness required as a precondition to renunciation. This idea is hinted at by a passage of the Birth, which explains that "in the Greeks, the 'will' wished to contemplate itself in the transfiguration of genius and the world of art" (BT: 44). It is expanded on more explicitly in the Nachlass. "we are on the one hand pure intuition, i.e. the projected images of a Being (...) which finds supreme rest in this intuition; on the other hand we are the unique Being itself. (...) When we feel ourselves as the unique Being, we are immediately elevated to the sphere of pure intuition, which is devoid of pain, although we also are, at the same time, pure will, pure suffering. But as long as we ourselves are merely the "represented", we do not partake in this absence of suffering, whereas the "representing" enjoys it in its purity" (KSA I 7 [175], see also 7 [157]). The first part of the quote takes up the idea that our very existence is an artistic projection of the will, meant to alleviate its suffering; it also confirms that there is no noumenal individuation ("we are the unique Being itself"). The rest of the passage emphasises the difference, on the one hand, between the perspective of the genius, which mirrors the will's standpoint, and that of ordinary men on the other: because of his excess of intellectual energy, which allows him to detach himself from the interested concerns of the everyday and thus to disclose ideas, not phenomena (cf WWR II: 379: "always to see the universal in the particular is precisely the fundamental characteristic of genius, whereas the normal man recognises in the particular only the particular as such"), the genius "feels himself as the unique being" and partakes in the stilling of the will, which makes it "devoid of pain". But the rest of us, who are unable to achieve this state and become the "eternal eye of the world", keep on suffering blindly, like the soldiers painted on canvas mentioned by the Birth. 
${ }^{15}$ Although I strongly disagree with Young's more general claim that the Birth's metaphysical assumptions are fully Schopenhauerian, and also with his conclusion that Nietzsche's version artistic redemption does not work, I do agree with him that on Schopenhauerian premises, this negative conclusion is valid. I actually would add three points to his criticism: the first is that even for the will, the redemption provided is unsatisfactory in the sense that it is never definitive: the will ceaselessly needs the influence of art to lull its pain — salvation is a promise constantly withheld. Secondly, on this Schopenhauerian-like view, the best art can do is to provide the will with a way to put up with life, but not generate the "raging desire for existence and joy in existence" (BT: 104-5) that Nietzsche evokes repeatedly (see also 59, which claims that « life is at the bottom of things (...) indestructibly powerful and pleasurable"). It can only provide a Quietiv, as Schopenhauer says, a sedative, not the positive motivation to go on living that Nietzsche insists on. Finally, the manner in which this sedation is effected is thoroughly dependent on the production of Apollonian illusions (the "images and artistic projections" of the will); the Dionysian plays not part at all in it (otherwise, the illusions would be exposed as such and lose their rapturous power), which is inconsistent with Nietzsche's claim that tragedy is a play between the Apollonian and the Dionysian, at the end of which, Apollo "speaks the language of Dionysus" (BT: 130). Therefore, this interpretation of artistic redemption is not only unsatisfactory; it also requires us to abandon the more Nietzschean aspects of the Birth to revert to a position that Schopenhauer himself explicitly rejected as inconsistent, namely the idea of a purely aesthetic redemption. For Schopenhauer indeed, art can only bring a temporary respite, a lull in which the will becomes aware for the first time, in particular through such art forms as tragedy, that its existence is noumenally doomed to pain. Therefore the only consistent attitude consists in the conversion described in book IV of WWR, whereby the ascetic takes the place of the genius in providing the will with a specific phenomenon through which it can not only acquire awareness, but also act on itself. The ascetic will then make the only logical choice and let the will to life extenuate itself as he starves his body; because there is no noumenal individuation, his death will be that of the whole world, and the circle of pain and boredom will be at last broken.

16 "Life as a continual spasm, projecting phenomena, and doing so with pleasure » 7 [204]

${ }^{17}$ See also BT, $104:$ : We are really for a brief moment primordial being itself, feeling its raging desire for existence and joy in existence; the struggle, the pain, the destruction of phenomena now appear necessary to us, in view of the excess of countless forms of existence which force and push one another into life, in view of the exuberant fertility of the universal will".

${ }^{18}$ This is a reference to Heraclitus' fragment 52: "the time (aiôn) of the world is a child playing: its kingdom is that of a child". See also « Attempt at Self Criticism », p. 22.

${ }^{19}$ Fink, 62 (my translation).

${ }^{20}$ Fink, 62 (my translation).

${ }^{21}$ Twilight of the Idols, X, 4. Quoted by Young on p. 137.

${ }^{22}$ L'érotisme, Paris: editions de Minuit, 1957, p. 18.

${ }^{23}$ Ibidem, 25.

${ }^{24}$ VII, 803 : "one must treat seriously all that is serious, and it is the God who is worthy of seriousness, while man is made to be a toy of the God".

${ }^{25}$ Ibidem.

${ }^{26}$ The Theory of the Novel : a Historico-Philosophical Essay on the Forms of Great Epic Literature, transl. Anna Bostock, London: Merlin Press, 1971.

${ }^{27}$ This also applies to the heroes; thus Achilles is defined by his wrath, on which the Iliad opens up.

${ }^{28}$ For example, Caesar claimed that he was descended from Aeneas, and therefore from Venus. On the justificatory function of the Greek myths, see Marc Richir, La naissance des Dieux. Paris: Points Seuil (Collection Pluriels), 1998.

${ }^{29}$ When Hector comes to say farewell to his wife and son on the walls of Troy, before his fight with Achilles, he knows that he will die, and that Andromache will suffer a cruel fate: "deep in my heart I know the day is coming when holy Ilium will be destroyed, with Priam and the people of Priam of the good ashen spear. Yet I am not so much distressed by the thought of what the Trojans will suffer (...) as by the thought of you, dragged off in tears by some Achaean man-at-arms in slavery. I see you there in Argos, toiling for some other woman at the loom, or carrying water from an alien well, a helpless drudge with no will of your own... Ah, may the earth lie deep on my dead body before I hear the scream you utter as they drag you off!" (Iliad, canto VI, 405). 
Andromache too is perfectly aware of her incoming fate: « Hector, you do not think of your little boy or your unhappy wife, whom you will make a widow soon... And when I lose you I might as well be dead. There will be no comfort left when you have met your doom - nothing but grief. I have no father, no mother, now. My father fell to the great Achilles when he sacked our lovely town. I had seven brothers, too, at home. In one day all of them went down to Hades' House... So you, Hector, are father and mother and brother to me, and well as my beloved husband. Do not make your boy an orphan and your wife a widow ».

${ }^{30}$ BT, 62, my emphasis. The " geniuses of nature » are satyrs, cf below.

${ }^{31}$ To see music as symbolical represents another point of departure from the Schopenhauerian view, which considers music as the direct expression of the will.

${ }^{32}$ The Birth provides an ontological explanation of the creative process. Nietzsche's later work, however, will discard the metaphysical assumptions of the Birth and produce a psychological analysis of this sublimation process. The precondition for artistic production becomes "physiological", and is identified as "frenzy" (Rausch, which is the term used by the Birth to characterise the Dionysian). "Frenzy must have enhanced the excitability of the whole machine; else, there is no art" (TI IX 8). A passage of the Will to Power specifies the nature of the artistic process. The artist must experience both "intoxication", as a "feeling of enhanced power", and an "extreme sharpness of certain senses" (WP §428); when both reach an almost unbearable point, he feels the "need to get rid of oneself, as it were, through signs and gestures, (...) through a hundred speech media" (WP §429), whereby the work is created. Good, classical art reaches a perfect balance between the richness of the perceptive content and its expression through figure and form — the "yoke" (WP §446) characteristic of grand style.

33 "We must conceive of the folk song as the musical mirror of the world, as the original melody, now seeking for itself a parallel dream phenomenon and expressing it in poetry. Melody is therefore primary and universal". BT, 53.

${ }^{34} \mathrm{Cf}$ also 66: "Dionysus no longer speaks through forces but as an epic hero, almost in the language of Homer".

${ }^{35}$ On the "metaphysical joy" induced by tragedy, see M. Haar's chapter, "Tragic joy", in Nietzsche and Metaphysics.

${ }^{36}$ See also: "the demand of the artist that he should practice the perspective of the audience (...) means to demand that he should impoverish himself and his creative power" (WP, §429).

${ }^{37}$ Schopenhauer criticizes the privative understanding of nothingness inherited from Descartes, and hints that true nothingness is a positive state (a Hinduist idea which comes from his reading of the Vedantas).

${ }^{38}$ Another example is Porter's claim that "[the will's] ultimate grounding appears to lie in its mere conceivability and (what amounts to the same thing) in its incoherence" (Porter: 62). I hope to have shown above that Nietzsche's views on the will, when analysed carefully and pried away from Schopenhauer's, are not incoherent; moreover, it is difficult to see how the conceivability of something can rightfully be identified with its incoherence.

${ }^{39}$ Poellner's article does not only focus on the Birth but also on the Second Untimely Meditation. For lack of space, I shall only summarise and address here his criticisms of the Birth's metaphysics.

${ }^{40}$ The implicit assimilation between illusion and error is debatable as one could argue, as did Kant, that illusion is caused by faulty perception while error results from defective judgment, and thus that illusions are not in themselves erroneous.

${ }^{41}$ Neville Morley makes a similar argument in a later paper entitled "Unhistorical Greeks", in Nietzsche and Antiquity: His Reaction and Response to the Classical Tradition, ed. Paul Bishop, Rochester: Camden House, 2004, in particular in the following passage: "As history, [BT] is implausible; but the account is offered explicitly as a parable,a new myth. If, as Nietzsche argues, we can never gain a true knowledge of the past, if our stories about it are always determined by our present concerns, then the main criterion for judging between different versions must be their "usefulness". One can idealise the Greeks as the first historians, a myth that serves to legitimise us and our activity as their heirs and as the culmination of what they began. (...) The question remains: if a myth is known to be a myth, can it still work?".

${ }^{42} \mathrm{Cf}$. «Attempt at Self-Critique », §5 p. 23.

${ }^{43} \mathrm{Cf}$. «Attempt at Self-Critique », §2 p. 18, the book is said to be "close to the limits of communication", which brings me to my next point. 
${ }^{44}$ I. Kant, Critique of Pure Reason, (transl. Nelson Kemp Smith, London: Mc Millan Press, 1995), A 797/B825, p. 630. It is also a Schopenhauerian theme. Cf. WWR, "The metaphysical need of humanity". The notion of a "metaphysical drive" is taken up in the Nachlass, cf. for example KSA III, 19 [138].

${ }^{45}$ Cf. KSA III: 19 [140]: "time in-itself is an absurdity: time only exists for a being endowed with sensibility. Idem for space". See also 19 [156]: "a quality only exists for us, i.e. as measured by us. If we remove measure, what remains of the quality!" and 19 [158].

${ }^{46} \mathrm{Cf}$. "On Truth and Lies in the Non Moral sense », in Philosophy and Truth: Selections from Nietzsche's

Notebooks of the Early 1870's (editor and translator D. Breazale, New York: Humanity books, 1979, p. 79-100, where Nietzsche develops this idea through the famous example of the Chladni figures. For an interesting interpretation of this controversial text, which shows De Man's influential reading to be wrong, see Maudemarie Clark (1990: 63-96).

${ }^{47}$ Perhaps its most objectionable consequence is that because it invalidates the possibility of objective empirical knowledge (which Kant was very keen to preserve), it removes the very distinction between empirical and metaphysical claims.

${ }^{48}$ cf KSA III : 19 [123] : « one cannot demonstrate the metaphysical signification of existence, nor its ethical signification, nor its aesthetic signification" (Nietzsche's italics).

${ }^{49} \mathrm{cf}$. KSA III : 19 [76] : «That an impossible to demonstrate philosophy may retain its value more, generally speaking, than a scientific theorem, that is explained that the aesthetic value of such a philosophy, i.e. by its beauty and its sublimity. It still exists as an artwork"(Nietzsche's italics).

${ }^{50} \mathrm{cf}$. for example: "the real purpose of myth is not a present an objective picture of the world as it is, but to express man's understanding of himself in the world in which he lives. Myth should be interpreted not cosmologically, but anthropologically, or better still, existentially". (Bultmann: 1953, 10). See also Jesus Christ and Mythology, New York, 1958, in particular p. 19 sq. For a short analysis of Bultmann's understanding of myth, see Robert A. Segal, "The Existentialist Interpretation of Myth", in Myth and the Making of Modernity. The Problem of Grounding in Early Twentieth-Century Literature, M. Bell and P. Poellner eds, Amsterdam Atlanta: Rodopi, p. 114-124).

${ }^{51}$ As seen above, the notion of symbolisation is heavily used by Nietzsche in the Birth to characterise artistic processes (in particular, the relation of the Apollonian to the Dionysian, of music to the will, of man to nature). ${ }^{52}$ For a criticism of the rationalist approach to myth, see BT: $\S 10,75$ and $\S 23,136$.

${ }^{53}$ One could argue (pretty much as Spinoza does in the Ethics to account for the passage from knowledge of the first type to knowledge of the second type) that a fortuitous encounter with the myth may reawaken our atrophied artistic abilities and thus indicate to us the way to transmute pain into pleasure, but (as with Spinoza) the likelihood of this happening is low.

${ }^{54}$ Thus a passage of the Birth equates the contrast between the "real truth of nature and the lie of culture" with "that between the eternal core of things, the thing-in-itself, and the whole world of appearances" (BT: $§ 8,61$ ). Cf. also Schopenhauer Educator: "To be truthful means: to believe in an existence that can in no way be denied and which is itself true and without falsehood. That is why the truthful man feels that the meaning of his activity is metaphysical, explicable through the laws of another and higher life, and in the profoundest sense affirmative" (SE, 153).

${ }^{55}$ (only from the Gay Science onwards will he reject it, along with the distinction between the in-itself and appearances). 